\title{
Islet B-cell dysfunction and the time course of recovery following chronic overinsulinisation of normal rats
}

\author{
Y.T.Kruszynska ${ }^{1}$, L. Villa-Komaroff ${ }^{2}$ and P.A. Halban ${ }^{1,3}$ \\ 1 Joslin Diabetes Center, Brigham and Women's Hospital, and \\ ${ }^{2}$ Department of Neuroscience, Children's Hospital, Boston, Massachusetts, USA, and \\ ${ }^{3}$ Laboratories Jeantet, University of Geneva Medical School, Switzerland
}

\begin{abstract}
Summary. Appropriate insulin therapy may preserve or improve islet B-cell function whereas the effects of overinsulinisation are unclear. Pancreatic islet B-cell function was therefore studied after overinsulinisation of normal rats for 4 weeks (fed blood glucose $2.2-4.5 \mathrm{mmol} / 1$, controls 4.1-7.0 mmol/1). Insulin secretion was assessed by a $3-\mathrm{h}$ hyperglycaemic clamp $(10.0 \mathrm{mmol} / \mathrm{l})$ performed 1,48 , and $120 \mathrm{~h}$ after insulin withdrawal ( $n=6$ in each group). When the clamp was performed $1 \mathrm{~h}$ after insulin withdrawal, clamp insulin concentration was $1.6 \pm 0.1 \mu \mathrm{g} / 1$, compared to $9.3 \pm 1.0 \mu \mathrm{g} / 1$ in control rats. The integrated area under the plasma insulin concentration curve was also significantly decreased $\left(4.8 \pm 0.4\right.$ vs $\left.20.3 \pm 2.2 \mu \mathrm{g} \cdot \mathrm{l}^{-1} \cdot \mathrm{h}^{-1}, p<0.001\right)$, but recovered to $9.4 \pm 1.0 \mu \mathrm{g} \cdot 1^{-1} \cdot \mathrm{h}^{-1}$ after $48 \mathrm{~h}$, and to
\end{abstract}

$17.5 \pm 1.4 \mu \mathrm{g} \cdot 1^{-1} \cdot \mathrm{h}^{-1}$ after $120 \mathrm{~h}$. Pancreatic insulin contents were decreased at $1 \mathrm{~h}(6 \pm 1 \mu \mathrm{g} / \mathrm{g}$ wet wt) and $48 \mathrm{~h}$ (54 $\pm 12 \mu \mathrm{g} / \mathrm{g}$ wet wt) but not at $120 \mathrm{~h}(221 \pm 30 \mu \mathrm{g} / \mathrm{g}$ wet wt) after withdrawal (controls, $303 \pm 29 \mu \mathrm{g} / \mathrm{g}$ wet wt) and there was a strong relationship with pancreatic preproinsulin mRNA and the clamp insulin response. Thus, overinsulinisation with prolonged periods of low blood glucose concentrations impairs islet B-cell function, but is reversible over 5 days.

Key words: Insulin overtreated rats, insulin secretion, hyperglycaemic glucose clamp, pancreatic insulin content, preproinsulin mRNA.
Current management of the Type 1 (insulin-dependent) diabetic patient emphasises tight metabolic control in an effort to prevent the late tissue complications of diabetes, and in the early phase to preserve residual islet B-cell function. Intensive insulin injection therapy is, however, associated with hyperinsulinaemia [1] and very commonly with long periods of asymptomatically low blood glucose concentrations [2]. By analogy with the transient diabetic state observed in patients and rats after successful removal of a functioning insulinoma [3-5], prolonged periods of hyperinsulinaemia and low blood glucose concentrations might be expected to impair rather than preserve islet B-cell function. As insulin secreting tumours may also produce other islet hormones [6], it is possible, however, that these might contribute to the observed impairment of normal islet B-cell function.

In order to study the effects of long-term overinsulinisation on islet B-cell function we have used a rat model in which fed blood glucose levels were kept below normal by daily subcutaneous insulin injection therapy. Islet B-cell function was assessed by the hyperglycaemic clamp technique [7] immediately after insulin withdrawal and also at 2 and 5 days after withdrawal to document the time course of B-cell recovery. To examine the relationship between impaired insulin biosynthesis and secretion we have also measured pancreatic insulin content and preproinsulin mRNA abundance.

\section{Materials and methods}

\section{Animals}

Male Sprague Dawley rats (Charles River, Wilmington, Mass, USA) were used. Rats weighing $130-140$ g were treated for 3 weeks with daily subcutaneous injections of highly purified protamine zinc insulin (PZI) (Hypurin, CPI Pharmaceuticals, Wrexham, Clwyd, UK). Doses ( 3 to $5 \mathrm{U} /$ day) were adjusted to maintain blood glucose concentrations in fed rats between 2.5 and $4.5 \mathrm{mmol} / 1$. These concentrations were chosen to be below those found in normal fed rats whilst being close to concentrations found in 24 -h fasted rats. Rats were then treated for a further 7 days with soluble insulin (Hoechst 21PH, Hoechst, Frankfurt am Main, FRG) delivered from subcutaneously implanted Alzet mini-osmotic pumps (154 mU/h; Alzet 2002, Palo 
Alto, Calif, USA). Blood glucose determinations were made three times a week on tail vein samples collected under ether anaesthesia. Indwelling cannulae for metabolic studies were implanted under ether anaesthesia in the external jugular and femoral veins $24 \mathrm{~h}$ before the experiment.

\section{Hyperglycaemic clamp studies}

Insulin secretion was assessed by the hyperglycaemic clamp technique in 8 normal control rats and in insulin overtreated rats, 1, 48, and $120 \mathrm{~h}$ after insulin withdrawal (A, B and C respectively; $n=6$ in each group). Rats were fasted for $6 \mathrm{~h}$ prior to study. In group A, after removal of Alzet pumps and food at 07.00 hours neutral soluble insulin (Humulin R, Eli Lilly, Indianapolis, Ind, USA) diluted in polygeline solution (Haemaccel, Hoechst) was infused intravenously for $5 \mathrm{~h}$. This was necessary to maintain normoglycaemia prior to the clamp in this group of rats. The infusion rate (approximately $36 \mathrm{mU} / \mathrm{h}$ ) was adjusted to maintain blood glucose between 3.5 and $4.5 \mathrm{mmol} / 1$. The insulin infusion was discontinued $1 \mathrm{~h}$ prior to the clamp to allow for clearance of insulin from the plasma compartment. Normal control rats, and insulin overtreated rats in groups B and $\mathrm{C}$ received an infusion of Haemaccel alone at the same rate $(0.04 \mathrm{ml} / \mathrm{h})$. . Hyperglycaemic clamp studies commenced at 13.00 hours. After a basal blood sample $(200 \mu \mathrm{l})$ for glucose and insulin determination, blood glucose was raised to $10.0 \mathrm{mmol} / 1$ and clamped at that level for $3 \mathrm{~h}$ by a variable infusion of a solution of $500 \mathrm{~g} / 1$ glucose in water. This was delivered via the jugular venous cannula from a Harvard syringe pump (Harvard apparatus, South Natick, Mass, USA). Blood samples for glucose $(30 \mu$ ) were taken at 5-10 min intervals from the femoral venous cannula and replaced with $0.15 \mathrm{~mol} / \mathrm{I}$ saline. Blood glucose concentration was monitored by the glucose oxidase method within $2 \mathrm{~min}$ of obtaining the sample. Blood samples for insulin $(200 \mu \mathrm{l})$ were obtained at $10,20,30,45$, $60 \mathrm{~min}$ and then at $30-\mathrm{min}$ intervals until $180 \mathrm{~min}$. The erythrocytes from these samples were washed with $0.15 \mathrm{~mol} / 1$ saline and returned to the animal via the femoral cannula.

At the end of the study the animals were anaesthetised by intravenous (i.v.) injection of amylobarbitone $(0.02 \mathrm{~g}$ in $200 \mu \mathrm{l}$ $0.15 \mathrm{~mol} / \mathrm{l}$ saline). The pancreas was excised, ground in liquid nitrogen and the powder stored at $-70^{\circ} \mathrm{C}$ for determination of pancreatic insulin content and preproinsulin mRNA abundance.

\section{Diurnal blood glucose profiles after insulin withdrawal}

Femoral venous cannulae were implanted $24 \mathrm{~h}$ prior to removal of Alzet pumps from 6 insulin overtreated rats. Six normal control rats were also studied. Animals were allowed free access to laboratory chow and water. Blood samples $(30 \mu \mathrm{l})$ were taken at $6 \mathrm{~h}$ intervals for $48 \mathrm{~h}$ after insulin withdrawal for measurement of blood glucose concentration.

\section{Pancreatic preproinsulin $m R N A$ determination}

Pancreatic RNA was extracted from aliquots of the frozen tissue as previously described $[8,9]$. Briefly, tissue was weighed on a balance precooled to liquid nitrogen temperature and approximately $0.5 \mathrm{~g}$ was homogenised in $5 \mathrm{~mol} / 1$ guanidinethiocyanate $/ 5 \% \mathrm{v} / \mathrm{v} \beta$-mercaptoethanol $/ 50 \mathrm{mmol} / 1$ Tris $\mathrm{HCl}, \mathrm{pH} 7.5$. RNA was isolated from the homogenate by centrifugation $(25000 \mathrm{rpm}, 36 \mathrm{~h}$ in an SW28s rotor) through a $5.7 \mathrm{~mol} / 1$ ceasium chloride cushion. The total amount of RNA recovered was measured by resuspending the RNA pellet obtained after centrifugation through $\mathrm{CsCl}$ and determining the $\mathrm{OD}_{260}$ in a Beckman spectrophotometer. To ascertain the integrity of the RNA preparations, 1-3 $\mu \mathrm{g}$ of total RNA was fractionated on $1 \%$ agarose $/ 2.2 \mathrm{~mol} / 1$ formaldehyde gels [10] and stained with ethidium bromide. The 28 s and 18s RNA were visualised under UV light and photographed. Samples were not used unless the ratio of 28s RNA: 18s RNA was 1.5:1 or greater. To determine the integrity of the preproinsulin RNA, RNA from the gels was transferred to nylon filters (Zetabind, AMF Cuno, Meridan, Conn, USA) and hybridised to cDNA probe as described below. For dot blots, $5 \mu \mathrm{g}$ of total RNA was added to $20 \mu \mathrm{l}$ of $10 \mathrm{X} \mathrm{SSC}(1 \mathrm{X} \mathrm{SSC}=0.15 \mathrm{~mol} / 1$ $\mathrm{NaCl} 0.015 \mathrm{~mol} / 1$ sodium citrate, $\mathrm{pH} 7.0$ ), containing $50 \% \mathrm{v} / \mathrm{v}$ formaldehyde, and heated at $65^{\circ} \mathrm{C}$ for $10 \mathrm{~min}$. After adding $60 \mu \mathrm{l} 15 \mathrm{X}$ $\mathrm{SSC}$, the solution was applied to a nylon filter using a Minifold apparatus (Schleicher and Schuell, Inc., Keene, NH, USA). Pancreatic RNA from all rats was applied to a single filter. The filter was dried and baked for $2 \mathrm{~h}$ at $60^{\circ} \mathrm{C}$. For assessment of preproinsulin mRNA abundance the filter was prehybridised at $65^{\circ} \mathrm{C}$ for at least $4 \mathrm{~h}$, and then hybridised at $42^{\circ} \mathrm{C}$ for $18 \mathrm{~h}$ with $5 \times 10^{6} \mathrm{cpm}$ of single stranded cDNA probe prepared as described below. After washing extensively, the filter was exposed to X-ray fillm with a Cronex intensifying screen (DuPont, Newton, Conn, USA) for $24 \mathrm{~h}$ at $-70^{\circ} \mathrm{C}$. The autoradiogram was scanned with a scanning densitometer and the area under each curve determined.

To prepare the single stranded probe, a 193 base pair fragment from the plasmid pr12-SV40-46 was subcloned into M13 mp 19 [11]. This fragment extends from BamHl site 8 bases from the initiator codon to an EcoRl site in the second intron and corresponds to the coding sequence for the B chain and part of the $C$ peptide [12]. Uniformly labelled, single-stranded DNA extending from the BamHl site to a Hind III site in the vector and complementary to the coding strand was synthesized using the M13 template [13].

\section{Other assays}

Insulin was measured by ethanol precipitation radioimmunoassay [14] (intra-assay coefficient of variation $6 \%$ ) using a rat or human standard (Eli Lilly) as appropriate. Pancreatic insulin was determined on acid ethanol extracts of tissue using a rat insulin standard.

\section{Statistical analysis}

Results are expressed as means \pm SEM. The areas under the plasma insulin concentration curves were calculated using the trapezoidal rule. Significance of differences was assessed using Student's unpaired t-test. A $p$ value of less than 0.05 was considered statistically significant.

\section{Results}

\section{Plasma insulin and blood glucose concentrations in ad libitum fed rats}

Plasma insulin concentrations in the overinsulinised animals during the last week of insulin therapy from subcutaneously implanted Alzet pumps were increased $(7.31 \pm 0.29 \mu \mathrm{g} / 1$, human insulin standard) compared with normal controls $(3.14 \pm 0.25 \mu \mathrm{g} / \mathrm{l}$, rat insulin standard). Mean blood glucose concentration in ad libitum fed overinsulinised rats $(n=24)$ was $3.3 \pm 0.1 \mathrm{mmol} / 1$ compared with $5.6 \pm 0.2 \mathrm{mmol} / 1$ in normal controls $(n=14)$. This compares with a blood glucose concentration of $3.6 \pm 0.2 \mathrm{mmol} / 1$ in 12 normal rats after a $24 \mathrm{~h}$ fast. This chronic hypoglycaemia and hyperinsulinaemia was associated with increased food consumption and at the time of venous cannula- 


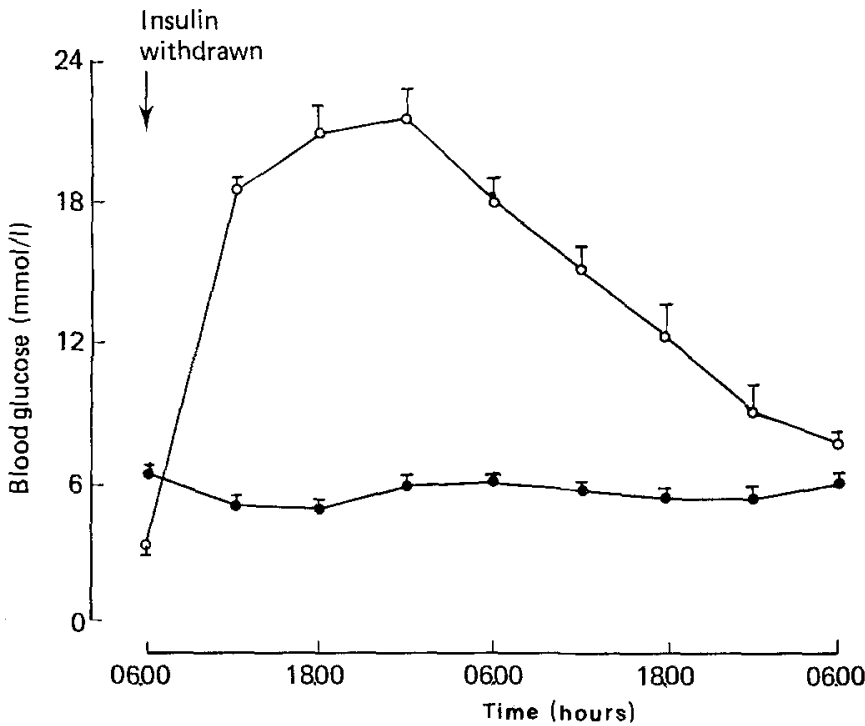

Fig. 1. Ad libitum fed blood glucose concentrations in 6 insulin overtreated rats after insulin withdrawal $\left(\mathrm{O}^{-}-\mathrm{O}\right)$ and 6 normal control rats $(\longrightarrow)$; mean \pm SEM

tion overinsulinised rats in group A were significantly heavier than the normal control rats $(336 \pm 8$ versus $298 \pm 4 \mathrm{~g}, p<0.001)$. Body weight remained significantly increased following insulin withdrawal (group B, $327 \pm 6 \mathrm{~g}$; group C $321 \pm 5 \mathrm{~g}$; both $p<0.01$ vs controls). After removal of Alzet pumps from a group of 6 rats, marked hyperglycaemia was observed within $6 \mathrm{~h}$ (Fig. 1). Blood glucose concentration remained elevated for $24 \mathrm{~h}$ (Fig.1) after which there was a steady decline until $48 \mathrm{~h}$ when concentrations in these ad libitum fed rats were not statistically significantly different from control rats $(t=2.111,0.05<p>0.1)$.

\section{Hyperglycaemic clamps}

After stopping the i.v. insulin infusion in group A (1 h before study), there was a progressive increase in blood glucose concentration from normoglycaemia $(4.2 \pm 0.1 \mathrm{mmol} / \mathrm{l})$ to $6.3 \pm 0.2 \mathrm{mmol} / 1$. Blood glucose concentration was then higher than in normal control rats $(4.5 \pm 0.1 \mathrm{mmol} / 1, p<0.001)$. Basal glucose concentrations before the clamp in overinsulinised rats $48 \mathrm{~h}$ (group B) and $120 \mathrm{~h}$ (group C) after insulin withdrawal were also increased compared with controls $(5.9 \pm 0.3 \mathrm{mmol} / 1$ and $5.1 \pm 0.1 \mathrm{mmol} / 1$, respectively, both $p<0.05$ ). Despite this difference in blood glucose, basal insulin concentrations in group $A$ $(1.32 \pm 0.23 \mu \mathrm{g} / \mathrm{l})$ were not different from those of control rats $(1.37 \pm 0.14 \mu \mathrm{g} / \mathrm{l})$. Basal insulin concentrations in group B $(2.17 \pm 0.28 \mu \mathrm{g} / \mathrm{l})$ and group C $(1.90 \pm 0.15 \mu \mathrm{g} / \mathrm{l})$ were significantly increased compared with controls (both $p<0.05$ ).

During the clamp target blood glucose of $10.0 \mathrm{mmol} / \mathrm{l}$ was attained by $15 \mathrm{~min}$ in all groups of rats (Fig.2). In groups A and B, glucose requirement to
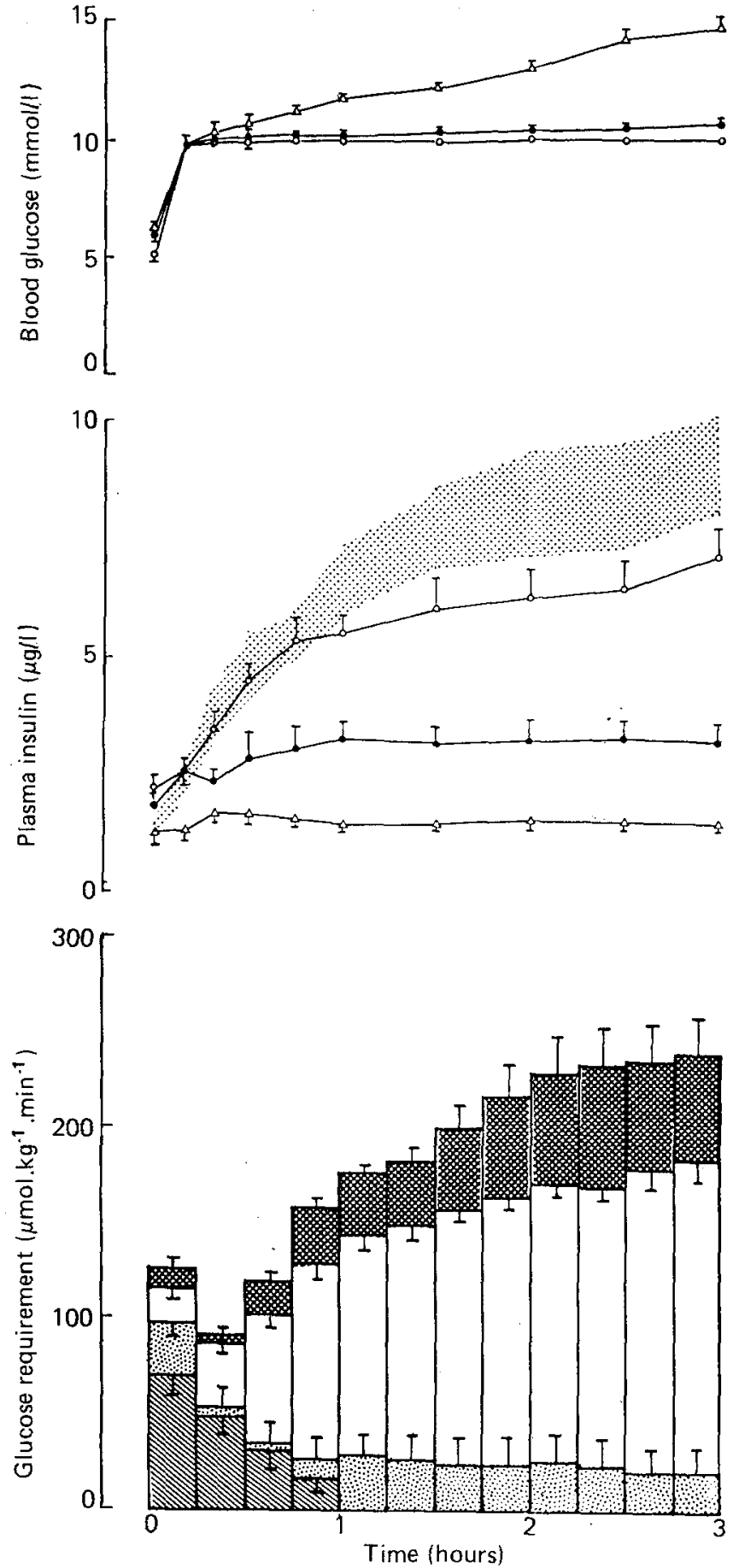

Fig. 2. Blood glucose (top) and plasma insulin (middle) responses to a hyperglycaemic clamp in overinsulinised rats $1 \mathrm{~h}(\triangle \triangle \Delta), 48 \mathrm{~h}$ $(-)$ and $120 \mathrm{~h}(\mathrm{O}-\mathrm{O})$ after insulin withdrawal $(n=6)$ in each group). The blood glucose concentration curve of control rats overlies that of the $120 \mathrm{~h}$ insulin withdrawn group and is not shown. Shaded area (middle panel) represents mean \pm SEM for normal control rats $(n=8)$. Bottom: glucose requirement to maintain the glucose clamp in rats $1 \mathrm{~h}(\mathbb{Q}), 48 \mathrm{~h}(\mathrm{O})$ ) and $120 \mathrm{~h}(\square)$ after insulin withdrawal and in normal control rats $(\mathrm{Q})$

maintain the clamp (Fig. 2) rapidly decreased to very low. values after the initial prime, and was discontinued in all the group A rats and in 3 of the group B rats by $+60 \mathrm{~min}$. Despite stopping the glucose infusion, blood glucose concentration in group A rats continued to rise and was 
$14.6 \pm 0.6 \mathrm{mmol} / \mathrm{l}$ at $+180 \mathrm{~min}$ (Fig. $2, p<0.001 \mathrm{com}$ pared with controls). A small increase in blood glucose concentration was also observed in 3 rats in group B despite stopping the glucose infusion, accounting for the slightly higher glucose concentration at $+180 \mathrm{~min}$ in this group $(10.6 \pm 0.2 \mathrm{mmol} / \mathrm{l})$ compared with controls (10.0 $\pm 0.1 \mathrm{mmol} / \mathrm{l}, p<0.05)$. The mean blood glucose during the last $90 \mathrm{~min}$ of the clamp was $10.0 \pm$ $0.1 \mathrm{mmol} / 1( \pm \mathrm{SD})$ in group $\mathrm{C}$ and $10.0 \pm 0.1 \mathrm{mmol} / 1$ $( \pm \mathrm{SD})$ in the control group. In these two groups, the coefficient of variation of blood glucose level calculated for each animal was $4.1 \pm 0.9 \%( \pm S D)$ and $5.2 \pm 1.3 \%$ respectively. In group $\mathrm{C}$, the glucose infusion rate from +120 to +180 min remained significantly lower than in controls $\left(183 \pm 12\right.$ vs $240 \pm 20 \mu \mathrm{mol} \cdot \mathrm{min}^{-1} \cdot \mathrm{kg}^{-1}$, $p<0.05$ ).

Insulin secretion in normal control rats increased throughout the $3 \mathrm{~h}$ hyperglycaemic clamp and steady state plasma insulin levels were not attained during the study (Fig.2). Insulin secretion was markedly impaired in groups A and B (Fig.2), the areas under the plasma insulin concentration curves being significantly lower than in controls (Table 1 , both groups $p<0.001$ ). By $120 \mathrm{~h}$ after insulin withdrawal (group C) clamp insulin response was not different from control rats (Table 1 ).

\section{Pancreatic insulin and preproinsulin $m R N A$ content}

Pancreatic insulin concentration was decreased in groups $\mathrm{A}$ and $\mathrm{B}$ compared with control rats (Table 1 , $p<0.001$ for both) but not in group C $(221 \pm 30$ vs $303 \pm 29 \mu \mathrm{g} / \mathrm{g}$ wet wt, $t=1.992$, NS). Recovery of total pancreatic RNA was increased in group A rats compared with normal controls $(11.5 \pm 0.7$ vs $8.4 \pm 0.7$ $\mathrm{mg} / \mathrm{g}$ wet wt, $p<0.05$ ) but was similar in groups $B$ and $C(10.1 \pm 1.6$ and $7.5 \pm 0.9 \mathrm{mg} / \mathrm{g}$ wet wt respectively). In all cases the ratio of $28 \mathrm{~s}$ RNA to $18 \mathrm{~s}$ RNA was 1.5 to 1 or greater and the preproinsulin mRNA could be visualised, after hybridisation to a radiolabelled probe, as a broad but discrete band of about 550 bases. Relative concentrations of preproinsunn mRNA in aliquots of total pancreatic RNA are shown in Figure 3. The areas under the densitometric scanning curves were markedly decreased in group A rats compared with controls rats $(24 \pm 7$ vs $586 \pm 73 \mathrm{U} / 5 \mu \mathrm{g}$ RNA, $p<0.001$ ). By $48 \mathrm{~h}$ after insulin withdrawal, preproinsulin mRNA content had increased to $35 \%$ of control $(203 \pm 77 \mathrm{U} / 5 \mu \mathrm{g}$ RNA, $p<0.005)$ and by $120 \mathrm{~h}$ was not different from that of control rats ( $494 \pm 41 \mathrm{U} / 5 \mu \mathrm{g}$ RNA; Fig. 3). Within group B there was wide variation in the preproinsulin mRNA abundance (46-440 U/5 $\mu \mathrm{g}$ RNA) and pancreatic insulin contents $(21-97 \mu \mathrm{g} / \mathrm{g}$ wet wt) and a strong correlation was observed between these two variables $(r=0.95)$ and between pancreatic insulin content and insulin response to the hypyerglycaemic clamp $(r=0.83, p<0.05)$.
Table 1. Areas under the plasma insulin concentration curves (AUC) during the hyperglycaemic clamp and pancreatic insulin contents in overinsulinised rats $1 \mathrm{~h}$ (group A), $48 \mathrm{~h}$ (group B) and $120 \mathrm{~h}$ (group C) after insulin withdrawal and in normal control rats

\begin{tabular}{lcllll}
\hline & $\begin{array}{l}\text { Normal } \\
\text { rats }\end{array}$ & \multicolumn{3}{l}{ Insulin overtreated rats } \\
\cline { 3 - 6 } & 8 & 6 & 6 & 6 \\
\hline$n$ & Group A Group B & Group C \\
AUC $\left(\mu \mathrm{g} \cdot \mathrm{1}^{-1} \cdot \mathrm{h}^{-1}\right)$ & $20.3 \pm 2.2$ & $4.8 \pm 0.4$ & $9.4 \pm 1.0^{\mathrm{a}}$ & $17.5 \pm 1.4$
\end{tabular}

Pancreatic insulin

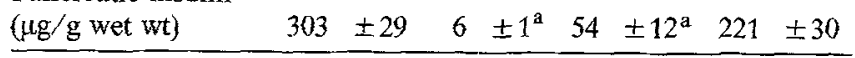

Mean \pm SEM

${ }^{a} p<0.001$ compared with normal control rats

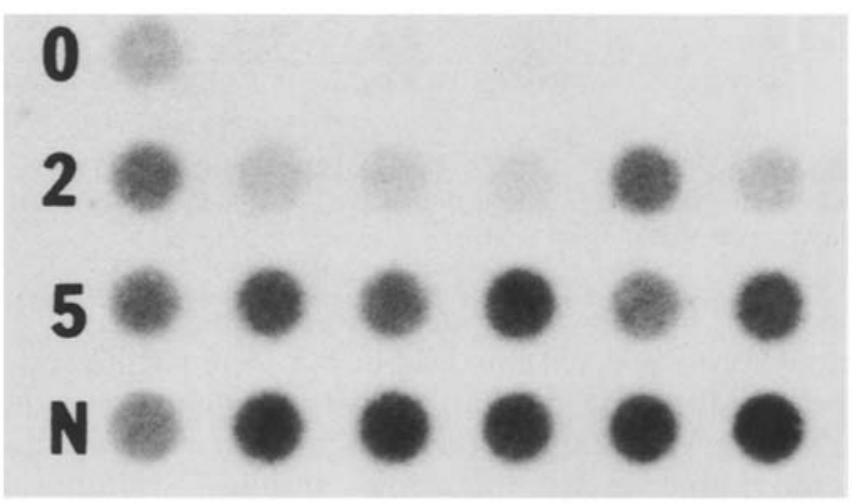

Fig.3. Autoradiograph showing relative concentrations of preproinsulin mRNA in aliquots of total pancreatic RNA, determined by dot hybridisation to cloned ${ }^{32} \mathrm{P}$-labelled cDNA probe. Each spot represents a single animal. Rows 0,2 , and 5 represent rats immediately, 2 and 5 days after insulin withdrawal. Bottom row $(N)$ represents 6 normal control rats

\section{Discussion}

In the present study we have examined the effects of chronic overinsulinisation on islet B-cell function in normal rats. Our findings of a transient diabetic state following insulin withdrawal are similar to those of Chick et al. [5] in rats with functioning insulinomas. That this impairment of B-cell function in rats with insulinomas is secondary to the hypoglycaemia rather than a direct feedback effect of insulin is suggested by the demonstration that prolonged intravenous glucose infusions led to B-cell recovery despite continuing tumour-associated hyperinsulinaemia [15]. Our findings may be contrasted with those of Chu and Goodner [16] who were unable to demonstrate abnormalities of insulin secretion following intravenous glucose and tolbutamide in normal rats treated by insulin injections for 5 months. These authors did, however, find a 50\% decrease in pancreatic insulin content in the insulin treated rats [16]. A more sustained hypoglycaemia in the current study might possibly account for the more profound effect demonstrated. The degree of hypoglycaemia achieved in the current study was, however, relatively mild, ad libitum fed blood glucose concen- 
trations being maintained close to levels found in normal fasted rats. Our observations are thus consistent with the decreased islet cell proliferation and islet volume found in food restricted rats and mice [17, 18], and suggest that blood glucose elevations in the fed state, albeit small, play an important trophic role for normal islet function.

Recovery of total RNA expressed per unit weight of frozen pancreatic tissue was increased $36 \%$ in group A rats compared with normal control rats. It is possible that this reflects the effect of hyperphagia and hyperinsulinaemia and hence increased glucose metabolism in the exocrine pancreas [19, 20]. Pancreatic preproinsulin mRNA was, however, profoundly decreased whether expressed in terms of pancreatic weight $(5.2 \%$ of normal control value) or as a proportion of total pancreatic RNA (4.1\% of control value).

Previous studies in rats chronically overinsulinised by insulin injection therapy have demonstrated both a decrease in number and size of islet $B$ cells and a decrease in B-cell granules [21, 22]. Similar features are seen in the pancreas of insulinoma-bearing rats [5, 23]. These changes are thus likely to account for the delay in recovery of B-cell function following insulin withdrawal or tumour resection. Indeed, studies in insulinoma-bearing rats infused intravenously for 3 days with $50 \%$ glucose resulted in both B-cell hypertrophy and increased B-cell replication [13] in addition to an increase in preproinsulin mRNA abundance. As in the current study, the increase in preproinsulin mRNA content was delayed until 2-3 days after reversal of hypoglycaemia [15]. In the 3 groups of overinsulinised rats we have been able to demonstrate a clear relationship between pancreatic preproinsulin mRNA abundance, pancreatic insulin content and clamp insulin response. These findings are in keeping with a regulatory role of glucose on preproinsulin gene transcription and possibly mRNA translation. Whether chronic overinsulinisation is associated with a defect of insulin release per se, as has been found in islets cultured at low glucose concentrations for 6 days [24, 25], cannot be answered from the current study. Such an abnormality if present would be very difficult to detect during the first $48 \mathrm{~h}$ after insulin withdrawal when both preproinsulin mRNA content and insulin content were profoundly decreased.

We have previously demonstrated that long-term overinsulinisation with mild hypoglycaemia is associated with a decrease in insulin sensitivity [26]. The elevated basal insulin and glucose concentrations in rats in groups $\mathrm{B}$ and $\mathrm{C}$ compared with control animals (Fig. 2) suggest that restoration of normal sensitivity is also delayed several days following insulin withdrawal. Interpretation however, is complicated by the increased body weights of the insulin overtreated animals.

Our findings may be important not only in relation to the insulin treated Type 1 diabetic patient with re- sidual B-cell function but also in relation to other groups with impaired B-cell function treated by exogenous insulin therapy. These include insulintreated Type 2 (non-insulin-dependent) diabetic patients, recipients of pancreatic transplants and patients who have undergone partial pancreatectomy. Although modest improvement in metabolic control in Type 2 diabetic patients $[27,28]$ has been associated with improved B-cell function it may be prudent to avoid overinsulinisation in these groups.

Further studies are needed to examine whether intermittent overinsulinisation, as is most frequently encountered in patients on intensified insulin regimens, leads to impaired B-cell function, or whether continuous overinsulinisation is necessary. The observation that in normal subjects infused with insulin for $1 \mathrm{~h}, \mathrm{C}$ peptide and insulin secretion remained suppressed for a period after return of blood glucose concentrations to basal levels [29] suggests that intermittent overinsulinisation may exert a significantly detrimental effect.

Acknowledgements. We thank Dr. D. Gross for the M13 insulin construction. The study was supported by the Greenwall Foundation and NIH Grant No DK35292. Dr. Y.Kruszynska was the recipient of a Wellcome Trust Travel Award.

\section{References}

1. Rizza RA, Gerich JE, Haymond MW, Westland RE, Hall LD, Clemens AH, Service FJ (1980) Control of blood sugar in insulin-dependent diabetes: comparison of an artificial pancreas, continuous subcutaneous insulin infusion and intensified conventional insulin therapy. $N$ Eng $J$ Med 303: 1313-1318

2. Pramming S, Thorsteinsson B, Bendtson $I$, Ronn B, Binder C (1985) Nocturnal hypoglycaemia in patients receiving conventional treatment with insulin. Br Med J 291: 376-379

3. Marks V, Rose FC (1981) Hypoglycaemia. Blackwell, Oxford, pp 134-137

4. Boucher BJ, Frankel RJ, Walters H, Abel M (1970) Rate of disappearance of endogenous insulin from the circulation after removal of insulinomas. Br Med J 1: 535-537

5. Chick WL, Warren S, Chute RN, Like AA, Lauris V, Ketchen KC (1977) A transplantable insulinoma in the rat. Proc Natl Acad Sci USA 74: 628-632

6. Berger M, Bordi C, Cuppers HJ, Berchtold P, Gries FA, Munterfering $\mathrm{H}$, Sailer R, Zimmermann H, Orci L (1983) Functional and morphologic characterization of human insulinomas. Diabetes 32: 921-931

7. Ferner RE, Ashworth L, Tronier B, Alberti KGMM (1986) Effects of short-term hyperglycaemia on insulin secretion in normal humans. Am J Physiol 250: E655-E611

8. Chirgwin JM, Przybyla AE, MacDonald RJ, Rutter WJ (1979) Isolation of biologically active ribonucleic acid from sources enriched in ribonuclease. Biochemistry 18: 5294-5299

9. Glisin V, Crkvenjakov R, Byjus C (1974) Ribonucleic acid isolated by caesium chloride centrifugation. Biochemistry 13 : 2633-2637

10. Lehrach H, Diamond D, Wozney JM, Boedtker H (1977) RNA molecular weight determinations by gel electrophoresis under denaturing conditions, a critical re-examination. Biochemistry 16: $4743-4751$

11. Lomedico PT (1982) Use of recombinant DNA technology to program eukaryotic cells to synthesize rat proinsulin: a rapid expression assay for cloned genes. Proc Natl Acad Sci USA 79: $5798-5802$ 
12. Lomedico PT, Rosenthal N, Efstratiadis A, Gilbert W, Kolodner $R$, Tizard R (1979) The structure and evolution of the two nonallelic rat preproinsulin genes. Cell 18: $545-558$

13. Messing J (1983) New M13 vectors for cloning. Methods Enzymol 101: 20-78

14. Heding LG (1972) Determination of total serum insulin (IRI) in insulin treated diabetic patients. Diabetologia 8:260-266

15. Appel MC, Kislauskis EH (1984) Effects of glucose infusion in rats with a functional insulinoma. Diabetes 33 [Suppl.1]: 82A

16. Chu PC, Goodner CJ (1968) Lack of functional suppression of pancreatic beta cells during chronic insulin replacement in the rat. Endocrinology 82: 296-302

17. Ashworth MA, Kerbel NC, Haist RE (1952) Effect of chronic caloric insufficiency on the growth of the islet tissue in obesehyperglycaemic mice. Metabolism 11: 342-348

18. Petersson B, Hellman B (1962) Long-term effects of restricted caloric intake on pancreatic islet tissue in obese-hyperglycaemic mice. Metabolism 11: 342-348

19. Mossner J, Logsdon CD, Williams JA, Goldfine ID (1985) Insulin, via its own receptor, regulates growth and amylase synthesis in pancreatic acinar AR42J cells. Diabetes 34: 891-897

20. Trimble ER, Rausch U, Kerh HF (1987) Changes in individual rates of pancreatic enzyme and isoenzyme biosynthesis in the obese Zucker rat. Biochem J 248: 771-777

21. Latta JS, Harvey HT (1942) Changes in the islets of Langerhans of the albino rat induced by insulin administration. Anat Rec 82: 281-295

22. Logothetopoulos J, Kaneko M, Wrenshall GA, Best CH (1964) Zinc, granulation and extractable insulin of islet cells following hyperglycaemia or prolonged treatment with insulin. In: Brolin SE, Hellman B, Knutson $H$ (eds) The structure and metabolism of the pancreatic islets. Pergamon, Oxford, pp 333-347

23. O'Hare MMT, Shaw C, Swanston-Flatt SK, Marcelli M, Buchanan KD, Flatt PR (1985) Influence of a transplantable insulino- ma on the pancreatic polypeptide in the rat. Diabetologia 28 : $157-160$

24. Chick WL, Lauris V, Flewelling JH, Andres KA, Woodruff JA (1973) Effect of glucose on beta cells in pancreatic monolayer cultures. Endocrinology 92: 212-218

25. Siegel EG, Wollheim CB, Janjic D, Ribes G, Sharp GWG (1983) Involvement of $\mathrm{Ca}^{2}+$ in the impaired glucose-induced insulin release from islets cultured at low glucose. Diabetes 32:993-1000

26. Kruszynska YT, Home PD, Alberti KGMM (1987) Insulin insensitivity and skeletal muscle enzyme activities in response to overinsulinisation in the rat. Metabolism 36: 281-285

27. Kosaka K, Kuzuya T, Akanuma Y, Hagura R (1980) Increase in insulin response after treatment of overt maturity-onset diabetes is independent of the mode of treatment. Diabetologia 18:23-28

28. Garvey WT, Olefsky JM, Griffin J, Hamman RF, Kolterman OG (1985) The effect of insulin treatment on insulin secretion and insulin action in type II diabetes mellitus. Diabetes 34: 222-234

29. Horwitz DL, Rubenstein AH, Reynolds C, Molnar GD, Yanaihara $N$ (1975) Prolonged suppression of insulin release by insulin-induced hypoglycaemia; demonstration by C-peptide assay. Horm Metab Res 7: 449-452

Received: 12 October 1987

and in revised form: 3 June 1988

Dr. Y.T. Kruszynska

Department of Medicine

Royal Free Hospital

Pond Street

Hampstead

London NW3 2QG

UK 